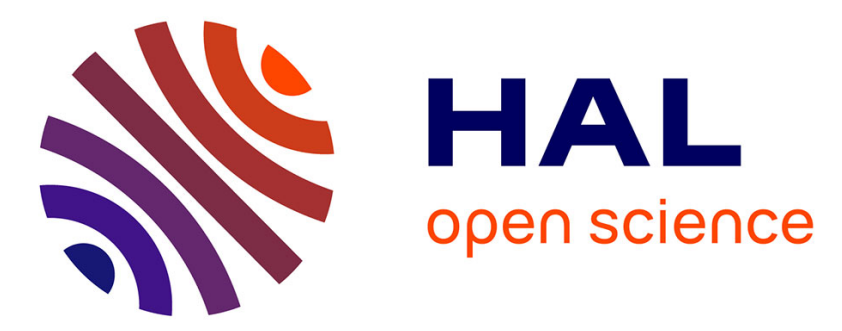

\title{
Release of the atrazine non-extractable (bound) residues of two soils using degradative techniques
}

Ludovic Loiseau, Enrique Barriuso, Yahya Zegouagh, Claude Largeau, André

A. Mariotti

\section{- To cite this version:}

Ludovic Loiseau, Enrique Barriuso, Yahya Zegouagh, Claude Largeau, André A. Mariotti. Release of the atrazine non-extractable (bound) residues of two soils using degradative techniques. Agronomie, 2000, 20 (5), pp.513-524. 10.1051/agro:2000146 . hal-00886058

\section{HAL Id: hal-00886058 \\ https://hal.science/hal-00886058}

Submitted on 1 Jan 2000

HAL is a multi-disciplinary open access archive for the deposit and dissemination of scientific research documents, whether they are published or not. The documents may come from teaching and research institutions in France or abroad, or from public or private research centers.
L'archive ouverte pluridisciplinaire HAL, est destinée au dépôt et à la diffusion de documents scientifiques de niveau recherche, publiés ou non, émanant des établissements d'enseignement et de recherche français ou étrangers, des laboratoires publics ou privés. 


\title{
Release of the atrazine non-extractable (bound) residues of two soils using degradative techniques
}

\author{
Ludovic LOISEAU $^{\mathrm{a} *}$, Enrique BARrIUSO ${ }^{\mathrm{a}}$, Yahya ZEGOUAGH ${ }^{\mathrm{b}}$, Claude LARGEAU $^{\mathrm{c}}$, \\ André MARIOTTI ${ }^{\mathrm{b}}$ \\ ${ }^{a}$ INRA, Unité de Science du Sol, BP 01, 78850 Thiverval-Grignon, France \\ ${ }^{\mathrm{b}}$ Université Pierre et Marie-Curie (CNRS-INRA) LBI, 4 Place Jussieu, 75252 Paris, France \\ ${ }^{c}$ ENSCP-CNRS, LCBOP, 11 rue Pierre et Marie-Curie, 75025 Paris, France
}

(Received 17 September 1999; revised 7 January 2000; accepted 10 February 2000)

\begin{abstract}
NaOH}$ extraction, $\mathrm{HF}$ treatment, and $\mathrm{HCl}$ hydrolysis applied on the humified fraction of two soils incubated with ${ }^{14} \mathrm{C}$-atrazine allowed to release between 77 and $89 \%$ of the total non-extractable (bound) residues of atrazine. Between 40 and $58 \%$ of the released ${ }^{14} \mathrm{C}$-bound residues were identified as the parent compound or degradation products (mainly hydroxy-atrazine). Humin seemed to be the most quantitative compartment responsible for the accumulation of the bound residues. A large part of bound residues was associated with the fulvic organic matter (only in the most acidic soil). In spite of the artefacts in relation to the transformation of extracted residues by the reagents used, important information is acquired about the identity of the bound residues and its association to the soil constituents.
\end{abstract}

atrazine / bound residue / alkaline extraction / acid hydrolysis / HF treatment

Résumé - Libération de résidus non-extractibles (liés) d'atrazine de deux sols par l'utilisation de techniques dégradatives. Des extractions alcalines $(\mathrm{NaOH})$, un traitement $\mathrm{HF}$, et une hydrolyse $\mathrm{HCl}$ de l'humine, appliquées aux fractions contenant la matière organique humifiée de deux sols, ont permis de libérer de 77 à $89 \%$ des résidus non-extractibles (liés) totaux d'atrazine. De 40 à $58 \%$ des ${ }^{14} \mathrm{C}$-résidus libérés ont été identifiés en tant que molécule mère et/ou produits de dégradation (principalement sous forme d'hydroxy-atrazine). L'humine semble être le principal compartiment où s'accumule les résidus liés. Une grande partie des résidus liés est associée à la matière organique fulvique dans le sol le plus acide. Malgré les artéfacts dus aux réactifs utilisés sur les résidus libérés, des informations ont été acquises quant à l'identité des résidus liés et leurs associations avec les constituants du sol.

atrazine / résidu lié / extraction alcaline / hydrolyse acide / traitement $\mathbf{H F}$

Communicated by Isabelle Lamy

* Correspondence and reprints

loiseau@ platon.grignon.inra.fr 


\section{Introduction}

The fate of most pesticides in soils is regulated by the retention phenomena. Adsorption is the first established phenomenon, its initial reversibility diminishes with time and the residues of the pesticides become non-desorbable. A part of these residues become non-extractable with the classical extraction techniques and are usually called "bound residues". The bound residues are defined as "chemical species originating from pesticides used according to good agricultural practice, that are unextracted by methods which do not significantly change the chemical structure of these residues" [25]. Due to the non-extractability of the bound residues, the use of radiolabelled molecules is needed to demonstrate their presence in soils. Bound residues formation concerns all the pesticides and their degradation products and ranges generally between 20 and $95 \%$ of the applied chemicals [9].

Bound residues can be considered as the result of a stabilisation process issue from the evolution of the retention phenomena. It is also considered as a pesticide dissipation phenomenon by some authors because the stabilised pesticides tend to lose their biological activity [9]. However, some studies showed that the bound residues can be uptaken by plants and earthworms [16, 21], released by microbial activity [12, 19,23] or physical changes of soils constituents $[19,26]$, and can have ecotoxicological effects $[1,2,27]$. The main proposed mechanisms to explain the formation of bound residues are generally related to the soil organic matter: covalent binding of the pesticides and its degradation products with the soil organic matter [8, 13], sequestration in the three-dimensional structure of the humic substances [13, 18].

Generally, the techniques used to study the pesticide bound residues in soils are based on techniques used to study the organic matter of soils: physical fractionation (giving information on the distribution of the bound residues in soil size fractions) $[5,7]$, chemical fractionation (giving information on the distribution of the bound residues in humic fractions and nature of the residues released) $[11,24$, 29], high temperature distillation (which supplies information on the nature of the bound residues) $[11,22]$, and ${ }^{13} \mathrm{C}$ or ${ }^{15} \mathrm{~N}$ NMR (which provides information on the nature of the bound residues and on the mechanisms involved in their formation) $[14,15,18]$.

The identification of the chemical nature of the residues involved in the bound residues is a compulsory step to better understand the mechanisms implied in the formation of bound residues, and to better predict the environmental hazards due to these residues. This study is focussed on the use of chemical techniques which enable the soil organic matter and the bound residues associated to these fractions to become soluble, in order to characterise the bound residues and to identify the main factors involved in the pesticide stabilisation in soils.

\section{Materials and methods}

\subsection{Soils}

Two French silty loam soils were studied. They are from the $0-20 \mathrm{~cm}$ layer of wheat-cultivated soil located in Grignon ( $\mathrm{G}$ soil) and from a maize-cultivated soil located in Versailles (V soil). Both soils have never been treated with atrazine in field conditions. Their main characteristics are summarised in Table I.

\subsection{Chemicals}

${ }^{14} \mathrm{C}$-ring-labelled atrazine (6-chloro- $\mathrm{N}^{2}$ ethyl$\mathrm{N}^{4}$ isopropyl-1,3,5-triazine-2, 4-diamine) was from Sigma. It had a radiochemical purity upper than $99 \%$ with specific activity of $7.9 \times 10^{8} \mathrm{~Bq} \cdot \mathrm{mmol}^{-1}$. An aliquot of the radiolabelled atrazine was mixed

Table I. Main characteristics of the two soils studied.

\begin{tabular}{lccccc}
\hline \multirow{2}{*}{ Soils } & Clay & Silt & Sand & $\begin{array}{c}\text { Organic } \\
\text { carbon }\end{array}$ & $\begin{array}{c}\mathrm{pH} \\
\text { (water) }\end{array}$ \\
\cline { 2 - 5 } & \multicolumn{5}{c}{$\left(\mathrm{g} \cdot \mathrm{kg}^{-1}\right)$} \\
\hline Grignon (G) & 269 & 590 & 124 & $17.4^{\mathrm{a}}$ & 8.0 \\
Versailles (V) & 168 & 527 & 304 & $13.4^{\mathrm{a}}$ & 6.4 \\
\hline
\end{tabular}

${ }^{a}$ Determined by combustion method (ISO 10694). 
with non-labelled atrazine from C.I.L. Cluzeau (analytic standard quality) in methanol to prepare the initial solution used for the application on soils. All the analytical standards of the atrazine metabolites were from C.I.L. Cluzeau.

\subsection{Incubation and bound residues recovering}

$60 \mathrm{~g}$ of the two fresh soils, sieved at $2 \mathrm{~mm}$, were placed in a closed glass flask to which ${ }^{14} \mathrm{C}$-ringlabelled atrazine and distilled water were added to give final concentrations of $0.5 \mathrm{mg} \cdot \mathrm{kg}^{-1}$ and $20 \mathrm{mg} \cdot \mathrm{kg}^{-1}$ for $\mathrm{G}$ (G-0.5 and G-20, respectively) and $0.5 \mathrm{mg} \cdot \mathrm{kg}^{-1}$ for $\mathrm{V}(\mathrm{V}-0.5)$, and a moisture content equivalent to $100 \%$ of the water-holding capacity. The low dose correspond to the agronomic dose, whereas the high dose was used to test the possible use of classical analytical techniques to identify the bound residues released. A vial with $2 \mathrm{ml}$ of $\mathrm{NaOH} 2 \mathrm{M}$ was placed in each flask and allowed to trap the ${ }^{14} \mathrm{C}-\mathrm{CO}_{2}$ released in order to quantify the atrazine mineralisation. These traps were periodi-

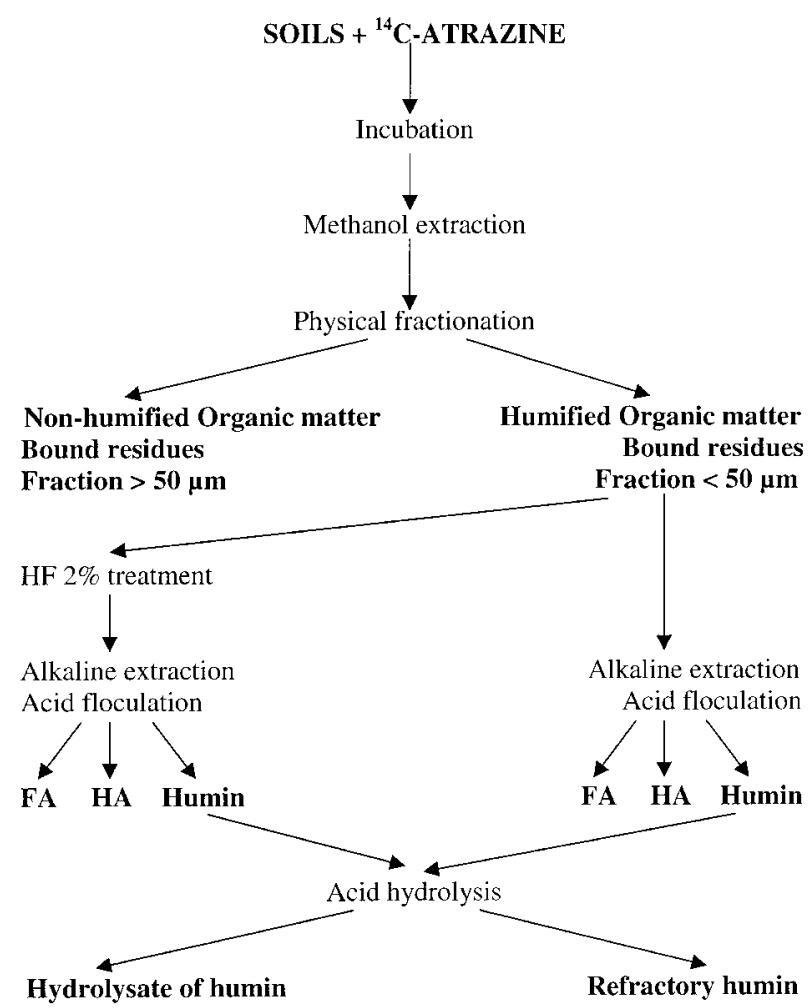

Figure 1. General protocol of soil fractionation. cally changed and the ${ }^{14} \mathrm{C}-\mathrm{CO}_{2}$ released determined by liquid scintillation counting. After 60 days of incubation at $28 \pm 2{ }^{\circ} \mathrm{C}$, in darkness, the soils were extracted (Fig. 1) with methanol $(1 \mathrm{w} / 2 \mathrm{v})$ in a $500 \mathrm{ml}$ polypropylene centrifuge bottle, shacked end-over-end for $24 \mathrm{~h}$, and centrifuged at $2500 \mathrm{~g}$ for 20 min (centrifuge Sorvall@ RC-5B). The supernatant was replaced with an equal volume of methanol and the pellet was dispersed by vigorous shaking. Methanol extractions were repeated until the extracted radioactivity was negligible, i.e. 5 times. The extracted pellets were then dispersed in water and sieved at $50 \mu \mathrm{m}$. The finest fraction $<50 \mu \mathrm{m}$ was recovered by centrifugation at $2500 \mathrm{~g}$ for $20 \mathrm{~min}$. The pellets were dried at $40 \pm 5^{\circ} \mathrm{C}$, weighed, and ground using an agate mortar.

\subsection{Alkaline extraction of the fraction $<50 \mu \mathrm{m}$}

$10 \mathrm{ml}$ of $\mathrm{NaOH} 0.1 \mathrm{M}$ were added to $5 \mathrm{~g}$ of the fraction in a $25 \mathrm{ml}$ glass centrifuge tube (Corex $\left.{ }^{\circledR}\right)$, shacked end-over-end for $16 \mathrm{~h}$ at $20 \pm 2{ }^{\circ} \mathrm{C}$, and centrifuged at $2500 \mathrm{~g}$ for $20 \mathrm{~min}$. The pellet was reextracted twice with $10 \mathrm{ml}$ of $\mathrm{NaOH} 0.1 \mathrm{M}$ for $1 \mathrm{~h}$ and then washed twice with $10 \mathrm{ml}$ of distilled water, the solid residue obtained (containing the humin) was dried at $40 \pm 5^{\circ} \mathrm{C}$, weighed, and ground using an agate mortar. The combined $\mathrm{NaOH}$ extracts and washings contained humic and fulvic acids (HA and FA, respectively). HA were precipitated at $\mathrm{pH}=1.5$ with $\mathrm{HCl}$ (pH-meter Tacussel LPH 230T with a combined electrode Radiometer analytical $\mathrm{XC100)}$ ). After $16 \mathrm{~h}$ this solution was centrifuged at $2500 \mathrm{~g}$ for $20 \mathrm{~min}$ and the supernatant containing FA was recovered. The precipited HA was dissolved in $10 \mathrm{ml}$ of $\mathrm{NaOH} 0.1 \mathrm{M}$. The radioactivity of HA, FA, and humin was measured by liquid scintillation counting. The $\mathrm{pH}$ of the FA solutions was adjusted to 11 with $\mathrm{NaOH}$.

Control experiments were conducted in the same way with an atrazine solution without soil in order to evaluate the artefacts due to $\mathrm{NaOH}$ treatment on atrazine transformation.

\subsection{Hydrolysis of humins}

Hydrolysis of humins was conducted for the humins obtained from G-20 and V-0.5. $20 \mathrm{ml}$ of 
$\mathrm{HCl} 2 \mathrm{M}$ were added to $3 \mathrm{~g}$ of the humins obtained by alkaline extraction in a $100 \mathrm{ml}$ glass balloon flask. The humin suspensions were heated at reflux for $24 \mathrm{~h}$, and then cooled and centrifuged at $2500 \mathrm{~g}$ for $20 \mathrm{~min}$. The pellets were washed twice with $15 \mathrm{ml}$ of distilled water and dried at $40 \pm 5^{\circ} \mathrm{C}$. Radioactivity of the combined $\mathrm{HCl} 2 \mathrm{M}$ extracts and washings were measured and the $\mathrm{pH}$ was adjusted to 11 with $\mathrm{NaOH}$.

\subsection{HF treatment of the fraction $<50 \mu \mathrm{m}$}

HF treatment was conducted for the fraction $<50 \mu \mathrm{m}$ from G-20 and V-0.5. This treatment was adapted from Skjernstad et al. [28]. $250 \mathrm{ml}$ of HF $2 \%$ were added to $18 \mathrm{~g}$ of fractions $<50 \mu \mathrm{m}$ in a $500 \mathrm{ml}$ polypropylene centrifuge bottles, shacked endover-end for $1 \mathrm{~h}$ at $20 \pm 2{ }^{\circ} \mathrm{C}$, and centrifuged at $6800 \mathrm{~g}$ for $20 \mathrm{~min}$. The supernatant was replaced with an equal volume of HF $2 \%$ and the pellet was dispersed by vigorous shaking. The complete treatment consisted in 5 successive extractions of $1 \mathrm{~h}$, then 3 extractions of $16 \mathrm{~h}$, and finally 1 extraction of $64 \mathrm{~h}$. At the end of the HF treatment, the solid residues were washed four times with water, dried at $40 \pm 5{ }^{\circ} \mathrm{C}$, weighed, and ground using an agate mortar. The radioactivity in the HF extracts was determined. $150 \mathrm{mg}$ of the HF residues were submitted to alkaline extraction, following a similar protocol than used previously, with radioactive content measurement in the FA, HA, and humin fractions. Then, $100 \mathrm{mg}$ of the humin obtained was submitted to $\mathrm{HCl}$ hydrolysis as described previously.

Control experiments were conducted in the same way with an atrazine solution without soil in order to evaluate the artefacts due to HF treatment on atrazine transformation.

\subsection{Analysis}

The radioactive content of the liquid samples was determined by liquid scintillation counting (Kontron Instruments Betamatic $\mathrm{V}$ counter) with quenching correction by external standard. $1 \mathrm{ml}$ of the samples was mixed with $10 \mathrm{ml}$ of the scintillation cocktail (Packard Ultima Gold ${ }^{\mathrm{TM}} \mathrm{XR}$ ).
The radioactivity of the solid samples was determined by liquid scintillation counting of the ${ }^{14} \mathrm{C}$ $\mathrm{CO}_{2}$ released from the sample combustion on a 307 Packard Sample Oxidizer, in which the solid samples are combusted at $800^{\circ} \mathrm{C}$ under oxygen flow; the ${ }^{14} \mathrm{C}-\mathrm{CO}_{2}$ formed is trapped in $8 \mathrm{ml}$ of Carbosorb®E Packard and mixed with $12 \mathrm{ml}$ of Permafluor ${ }^{\circledR}+$ Packard.

The $\mathrm{pH}$ of all the liquid samples was adjusted to 11 with $\mathrm{NaOH}$. They were then filtered using paper filter (Whatman ${ }^{\circledR}$ Filter paper No. 4) and concentrated using a liquid-solid extraction cartridge (ENV+ Isolute ${ }^{\circledR}$ IST Ltd, mass sorbency $200 \mathrm{mg}$ ). The cartridges were previously activated by $6 \mathrm{ml}$ of methanol then $6 \mathrm{ml}$ of water, the liquid samples were passed through under vacuum and the cartridges were washed with $6 \mathrm{ml}$ of water following by $10 \mathrm{~min}$ of drying. They were then eluted with $12 \mathrm{ml}$ of methanol, which was concentrated by evaporation under vacuum to a volume of 0.5 to $1 \mathrm{ml}$, and directly analysed using High Pressure Liquid Chromatography (Autosampler Waters ${ }^{\mathrm{TM}}$ 717 , System controller Waters $\left.{ }^{\mathrm{TM}} 600 \mathrm{E}\right)$ with a photodioide array detector (Waters ${ }^{\mathrm{TM}}$ 996) coupled online to a radioactive detector (Radiomatic Flo-One Series A-500 Packard) with a scintillation liquid flow (Packard Ultima Flo ${ }^{\mathrm{TM}} \mathrm{AP}$ ) of $3 \mathrm{ml} \cdot \mathrm{min}^{-1}$. The column was a Waters Nova-Pak ${ }^{\circledR}$ C18 $\left(60 \mathrm{~A}^{\circ}\right.$, $4 \mu \mathrm{m}, 4.6 \times 250 \mathrm{~mm}$ ) with a mobile phase flow of $1 \mathrm{ml} \cdot \mathrm{min}^{-1}$. The composition and the gradient used for the mobile phase is summarised in Table II. The volume injected was between $200 \mu \mathrm{l}$ and $500 \mu \mathrm{l}$, depending on the radioactive content of the samples.

Table II. Solvent composition and elution conditions for the HPLC analysis.

\begin{tabular}{|c|c|c|c|c|c|}
\hline \multirow{3}{*}{ Solvent } & \multicolumn{5}{|c|}{ Elution time (min) } \\
\hline & 0 & 1 & 8 & 12 & 30 \\
\hline & \multicolumn{5}{|c|}{$(\%)$} \\
\hline $\begin{array}{l}\text { A: Water } \\
\text { Sodium dodecyl sulfate }(5 \mathrm{mM}) \\
\text { pH adjusted to } 2.8 \text { with } \mathrm{HCl}\end{array}$ & 100 & 62 & 60 & 40 & 0 \\
\hline $\begin{array}{l}\text { B: Water / methanol }(1 \mathrm{v} / 9 \mathrm{v}) \\
\text { Sodium dodecyl sulfate }(5 \mathrm{mM}) \\
\text { pH adjusted to } 2.8 \text { with } \mathrm{HCl}\end{array}$ & 0 & 38 & 40 & 60 & 100 \\
\hline
\end{tabular}


The total carbon (TC) of the solid samples was determined with a Total Organic Carbon Analyser (TOC-5050A, Shimadzu) coupled to a Solid Sample Module (SSM-5000A, Shimadzu), in which the samples are burned under oxygen flow at $900^{\circ} \mathrm{C}$. The $\mathrm{CO}_{2}$ produced by the combustion of the sample is measured by an IR detector. The inorganic carbon (IC) was determined with the same material but the samples are previously acidified by $0.5 \mathrm{ml}$ of $\mathrm{H}_{3} \mathrm{PO}_{4} 25 \%$ and then burned at $200{ }^{\circ} \mathrm{C}$. Finally, the total organic carbon (TOC) was determined by the difference between TC and IC. Three replicates of each solid sample were burned except for the humin obtained after HF $2 \%$ treatment for which there was material for only one measure.

\section{Results and discussion}

\subsection{Bound residue formation rates and their distribution in the soil size fractions}

The two soils studied were chosen because of their difference of $\mathrm{pH}$ values $(8.0$ for $\mathrm{G}$ soil, and 6.4 for $\mathrm{V}$ soil) and of the similar low activity of their microbial community enable to mineralised the triazine ring $[4,20]$.

After 60 days of incubation, the atrazine mineralised represented $25.0 \%$ of the applied atrazine for G-0.5, $23.0 \%$ for G-20, and $3.0 \%$ for $\mathrm{V}-0.5$ (Tab. III). The total extractable residues represented $46.7 \%$ of the initial atrazine for G- $0.5,53 \%$ for G-20 and $39.5 \%$ for V-0.5. In the extracts, the pro-

Table III. Distribution of the radioactivity from the ${ }^{14} \mathrm{C}$-atrazine between the mineralised, extracted and bound residues.

\begin{tabular}{lrcc}
\hline Soils & Mineralised & Extracted & $\begin{array}{c}\text { Bound } \\
\text { residues }\end{array}$ \\
\cline { 2 - 4 } & \multicolumn{3}{c}{ (\% applied atrazine) } \\
\hline G-0.5 & 25.0 & 46.7 & 27.3 \\
G-20 & 23.0 & 53.0 & 21.3 \\
V-0.5 & 3.0 & 39.5 & 57.5 \\
\hline
\end{tabular}

Table IV. Characterisation of the extracted ${ }^{14} \mathrm{C}$-residues after 60 days of incubation.

\begin{tabular}{lrrrrr}
\hline Soils & $\begin{array}{c}\text { Dealkylated } \\
\text { metabolites }\end{array}$ & $\begin{array}{c}\text { Atrazine Hydroxy- } \\
\text { atrazine }\end{array}$ & $\begin{array}{c}\text { Other } \\
\text { hydroxylated } \\
\text { metabolites }\end{array}$ & $\begin{array}{c}\text { Not } \\
\text { identified }\end{array}$ \\
\cline { 2 - 6 } & \multicolumn{5}{c}{ (\% applied atrazine) } \\
\hline G-0.5 & 16.3 & 14.3 & 5.4 & 0.6 & 10.1 \\
G-20 & 19.2 & 15.5 & 5.6 & 0.7 & 12.0 \\
V-0.5 & 3.9 & 13.5 & 11.0 & 2.1 & 9.0 \\
\hline
\end{tabular}

portions of non-degraded atrazine were similar in all samples, but the G soil (G-0.5 and G-20) contained more dealkylated metabolites (mainly deethyl-atrazine and deiosopropyl-atrazine) than hydroxylated metabolites, and V-0.5 contained more hydroxylated (mainly hydroxy-atrazine) than dealkylated metabolites (Tab. IV). These results can be in relation to the lower $\mathrm{pH}$ of $\mathrm{V}$ soil which favour the hydroxylation of the triazine ring.

The bound residues formation was larger in the acid soil than in alkaline soil. The total bound residues represented $27.3,21.3$ and $57.5 \%$ of the applied ${ }^{14} \mathrm{C}$-atrazine for G-0.5, G-20, and V-0.5, respectively. The amounts of ${ }^{14} \mathrm{C}$-bound residues in the fractions $<50 \mu \mathrm{m}$ and $>50 \mu \mathrm{m}$ represented respectively 20.9 and $6.4 \%$ of the applied ${ }^{14} \mathrm{C}$ atrazine for G-0.5, 17.5 and $3.8 \%$ for G-20, and 46.8 and $10.7 \%$ for $\mathrm{V}-0.5$. These results were in accordance with Barriuso et al. [7] who indicated that the bound residues of atrazine are mainly located in the finest fraction $(<50 \mu \mathrm{m})$ which is the most important fraction in weight (represented 83.5 and $67.4 \%$ of the total mass for $\mathrm{G}$ and $\mathrm{V}$ soils, respectively) and contains the well humified organic matter and most of the soil organic $\mathrm{C}$ [5] (73.5\% of the total organic C for G- 0.5 and G-20, and $66.7 \%$ for $\mathrm{V}-0.5$ ). On the other hand, the fractions $>50 \mu \mathrm{m}$ of G-0.5 and G-20, which contain the "fresh" or nonhumified organic matter but less organic $\mathrm{C}$ content, present higher concentrations of bound residues than the fractions $<50 \mu \mathrm{m}\left(0.2\right.$ and $5.2 \mathrm{mg} \cdot \mathrm{kg}^{-1}$ for the fractions $>50 \mu \mathrm{m}$ of G-0.5 and G-20, and 0.1 and $4.1 \mathrm{mg} \cdot \mathrm{kg}^{-1}$ for the fractions $<50 \mu \mathrm{m}$, respectively) which is an indication of a great potential to form bound residues [5, 7]. 
Table V. Distribution of ${ }^{14} \mathrm{C}$-bound residues of the humified $(<50 \mu \mathrm{m})$ fraction in fulvic acids (FA), humic acids (HA) and humin.

\begin{tabular}{|c|c|c|c|c|c|}
\hline Localisation & \multicolumn{2}{|c|}{$\begin{array}{c}\text { FA HA Humin } \\
\text { (\% bound residues })\end{array}$} & \multicolumn{3}{|c|}{$\begin{array}{c}\text { FA HA Humin } \\
\left(\%{ }^{14} \mathrm{C} \text { applied }\right)\end{array}$} \\
\hline G-0 & $0 \quad 1.0$ & 85. & 3 & 0 . & \\
\hline & 0.0 & & & 0. & \\
\hline$V-0.5$ & $40.6 \quad 0.0$ & 53.7 & 19.0 & 0.0 & 25.0 \\
\hline
\end{tabular}

It could be noticed that the distribution of the ${ }^{14} \mathrm{C}$-residues in $\mathrm{G}$ soils between mineralisation, extractable residues, and bound residues in the fractions $>50 \mu \mathrm{m}$ and $<50 \mu \mathrm{m}$ is not drastically altered by the different doses used. This was also observed by Gan et al. [17].

\subsection{Bound residue distribution in the fractions obtained by alkaline extraction}

Alkaline extraction of the humified $(<50 \mu \mathrm{m})$ fractions allowed separation of the soluble organic matter (FA and HA) from the non-soluble organic matter (or humin). The organic carbon made soluble represented 17.8 and $10.2 \%$ of the organic carbon of the fraction $<50 \mu \mathrm{m}$ for the $\mathrm{G}$ soils and V0.5 , respectively, and more than $90 \%$ of this carbon was in FA. Bound residues of atrazine are associated to these different fractions (Tab. V). For the three samples, the bound residues of the fraction $<50 \mu \mathrm{m}$ were mainly in the humin fraction $(85.0,75.1$ and $53.7 \%$ of the ${ }^{14} \mathrm{C}$-bound to the fraction $<50 \mu \mathrm{m}$ for G-0.5, G-20, and V-0.5, respectively) as the organic carbon $(82.2,89.8 \%$ of the organic carbon of the fraction $<50 \mu \mathrm{m}$ for G-20 and V-0.5). The different doses used for $\mathrm{G}$ soil seemed to not change the distribution of the bound residues between FA, HA, and humin.

The experimental conditions of the alkaline extractions did not allow recovering a significant amount of HA. Indeed, the alkaline-soluble bound residues were mainly recovered in the FA fraction for the three samples. The proportion of the bound residues in the FA fraction was largest in the most acid soil (V-0.5). The humin seemed to be an important place to accumulate bound residues, mainly in the more alkaline soil. That was also observed by Capriel and Haish [10]. In the soil with lowest $\mathrm{pH}$, the part of bound residues associated to FA increase. This trend to confirm Barriuso et al. [7] results, which found more bound residues associated to FA when the soil $\mathrm{pH}$ is low. These authors obtained a larger proportion of bound residues in FA and HA fractions than in the present study, that is may be in relation with the more drastic alkaline extraction using sodium pyrophosphate.

Most of the radioactivity in the FA fractions of G-20 and V- 0.5 corresponded to the free atrazine and its metabolites, mainly hydroxy-atrazine. Atrazine and hydroxy-atrazine represented respectively 8 and $55 \%$ of the ${ }^{14} \mathrm{C}$-bound residues released with the FA for G-20, and 2 and $72 \%$ for V-0.5. Larger hydroxy-atrazine proportion in the FA from $\mathrm{V}-0.5$ was in relation to the higher capacity of this soil to hydrolyse atrazine which is pointed out by the analyse of the methanol extracts (Tab. IV). Non-identified soluble radioactivity in the FA represented 36 and $26 \%$ of the radioactivity of the FA from G-20 and $\mathrm{V}-0.5$. That corresponds to the unknown metabolites or to the non-free radioactivity associated to the soluble organic matter of the FA. The control experiments showed that in the conditions used for alkaline extraction, some of the hydroxyatrazine analysed in the FA could be the result of the hydrolysis of the atrazine by $\mathrm{NaOH}$ (10\% of the atrazine was hydrolysed in the control experiments after $16 \mathrm{~h}$ ).

These results showed that the triazine ring was still present in the bound residues after $60 \mathrm{~d}$ of incubation, which was also found by Capriel et al. [11] with other techniques. The recovery of the ${ }^{14} \mathrm{C}$ residues as free molecular forms could indicate that a part of non-extractable residues were protected from the solvent used for extraction (methanol) by interactions implying acid groups of the soil organic matter or by entrapment in the organic colloids. Effectively, alkaline extraction provokes dissociation of acids groups with solubilisation of small organic molecules like FA. At the same time, the increase of the surface charge of the organic colloids modifies the macromolecular structure of colloids that become distended with an opening of the internal voids and a liberation of the entrapped residues. 
Table VI. Distribution of ${ }^{14} \mathrm{C}$-bound residues of the humified $(<50 \mu \mathrm{m})$ fraction in HF extracts, FA, HA, and humin obtained by alkaline extraction after HF treatment.

\begin{tabular}{llllllllll}
\hline Soils & HF & FA & HA Humin & HF & FA HA Humin \\
\cline { 2 - 9 } & \multicolumn{3}{c}{ (\% } & bound residues $)$ & \multicolumn{4}{c}{$(\%$} & ${ }^{14}$ C applied $)$ \\
\hline G-20 & 30.0 & 5.7 & 3.7 & 42.2 & 5.3 & 1.0 & 0.6 & 7.4 \\
V- 0.5 & 53.5 & 8.3 & 12.3 & 17.5 & 25.0 & 3.9 & 5.8 & 8.2 \\
\hline
\end{tabular}

\subsection{Bound residue distribution in the humic fractions after mineral destruction by HF treatment}

In view of the results obtained for the overall behaviour of atrazine in G-0.5 and G-20, HF treatment was conducted on the fractions $<50 \mu \mathrm{m}$ from G-20 and V-0.5. This treatment is used to make the mineral constituents of the soil soluble and was very efficient because the weight losses were higher than $95 \%$ of the weight of the fractions $<50 \mu \mathrm{m}$ of the two soils. During the HF treatment, some of the soil organic matter was released $(47.2$ and $41.2 \%$ of the organic carbon of the fraction $<50 \mu \mathrm{m}$ for G-20 and V-0.5, respectively), but the remaining non-soluble organic matter seems not drastically altered [28]. A part of the bound residues were released during HF treatment, corresponding to 30.0 and $53.5 \%$ of the ${ }^{14} \mathrm{C}$-bound to the fraction $<50 \mu \mathrm{m}$ for G-20 and V-0.5 respectively (Tab. VI). That represented a large part of the bound residues associated to the FA extracted directly without HF treatment as described previously. An additional amount of bound residues with a fulvic nature was released in the HF extracts when the mineral constituents were destroyed (76\% more for G-20, and $32 \%$ more for $\mathrm{V}-0.5$ ).

Mineral destruction allowed better soil organic solubilisation by alkaline solvents. 17.8 and $10.3 \%$ of the organic carbon of the fraction $<50 \mu \mathrm{m}$ were made soluble by alkaline extraction when conducted on the fraction $<50 \mu \mathrm{m}$ for G-20 and V-0.5, respectively, against 22.2 and $27.4 \%$ of the organic carbon of the fraction $<50 \mu \mathrm{m}$ obtained after HF treatment. Other that the additional fulvic material recovered, large molecules of HA become soluble. They were associated to humin when the mineral constituents are intact. This suggests that mineral components would have an important role by the way of physical protection of the soil organic matter and eventually, in lesser importance, by chemical bonding $[9,29]$.

The proportion of the bound residues associated to the HA was higher in the most acid soil: 3.7 and $12.3 \%$ of the bound residues of the fraction $<50 \mu \mathrm{m}$ were in the HA of G-20 and V-0.5 respectively. The bound residue content in the humin after HF treatment was larger in the alkaline soil than in the acid soil: 42.2 and $17.5 \%$ of the bound residues were in humin of the G-20 and V-0.5 respectively. In terms of initial radioactivity, the bound residues associated to the fulvic materials (HF extracts plus FA), the $\mathrm{HA}$, and the humin represented respectively $6.3,0.6$ and $7.4 \%$ of the initial applied atrazine for G-20 and 28.9, 5.8 and $8.2 \%$ for $\mathrm{V}-0.5$.

Metabolic profiles obtained for HF extracts of the two soils are illustrated in Figure 2. Balance of the soluble radioactivity from the ${ }^{14} \mathrm{C}$-bound residues released in the HF extracts and in FA after HF treatment is done in Figure 3. The non-identified ${ }^{14} \mathrm{C}$-residues represented the most important products released for $\mathrm{G}-20\left(23.4 \%\right.$ of the ${ }^{14} \mathrm{C}$ in the fraction $<50 \mu \mathrm{m}$ ), contrary to $\mathrm{V}-0.5$ for which hydroxy-atrazine is the most important product released $\left(36.6 \%\right.$ of the ${ }^{14} \mathrm{C}$ in the fraction $\left.<50 \mu \mathrm{m}\right)$. Atrazine represented $4.2 \%(0.7 \%$ of the applied atrazine) and $2.5 \%\left(1.2 \%\right.$ of the applied $\left.{ }^{14} \mathrm{C}\right)$ of the bound residues associated to the fraction $<50 \mu \mathrm{m}$ for G-20 and V-0.5, respectively and hydroxyatrazine represented $4.5 \%\left(0.8 \%\right.$ of the applied $\left.{ }^{14} \mathrm{C}\right)$ and $36.6 \%\left(17.1 \%\right.$ of the applied $\left.{ }^{14} \mathrm{C}\right)$. More than $80 \%$ of the radioactivity released by HF treatment were released during the first five extractions $(8 \mathrm{~h}$ after the beginning of this treatment). The control experiments showed that $25 \%$ of the atrazine was hydrolysed in hydroxy-atrazine after $8 \mathrm{~h}$ (Fig. 4). In spite of artefacts, these results confirmed the persistence of the triazine ring in bound form and also the formation of bound residues by physical entrapment. This mechanism of formation of bound residues was also observed by Guthrie et al. [18] for ${ }^{13} \mathrm{C}$-pyrene in sediment, and Dec et al. [14] for cyprodinil in soil. 

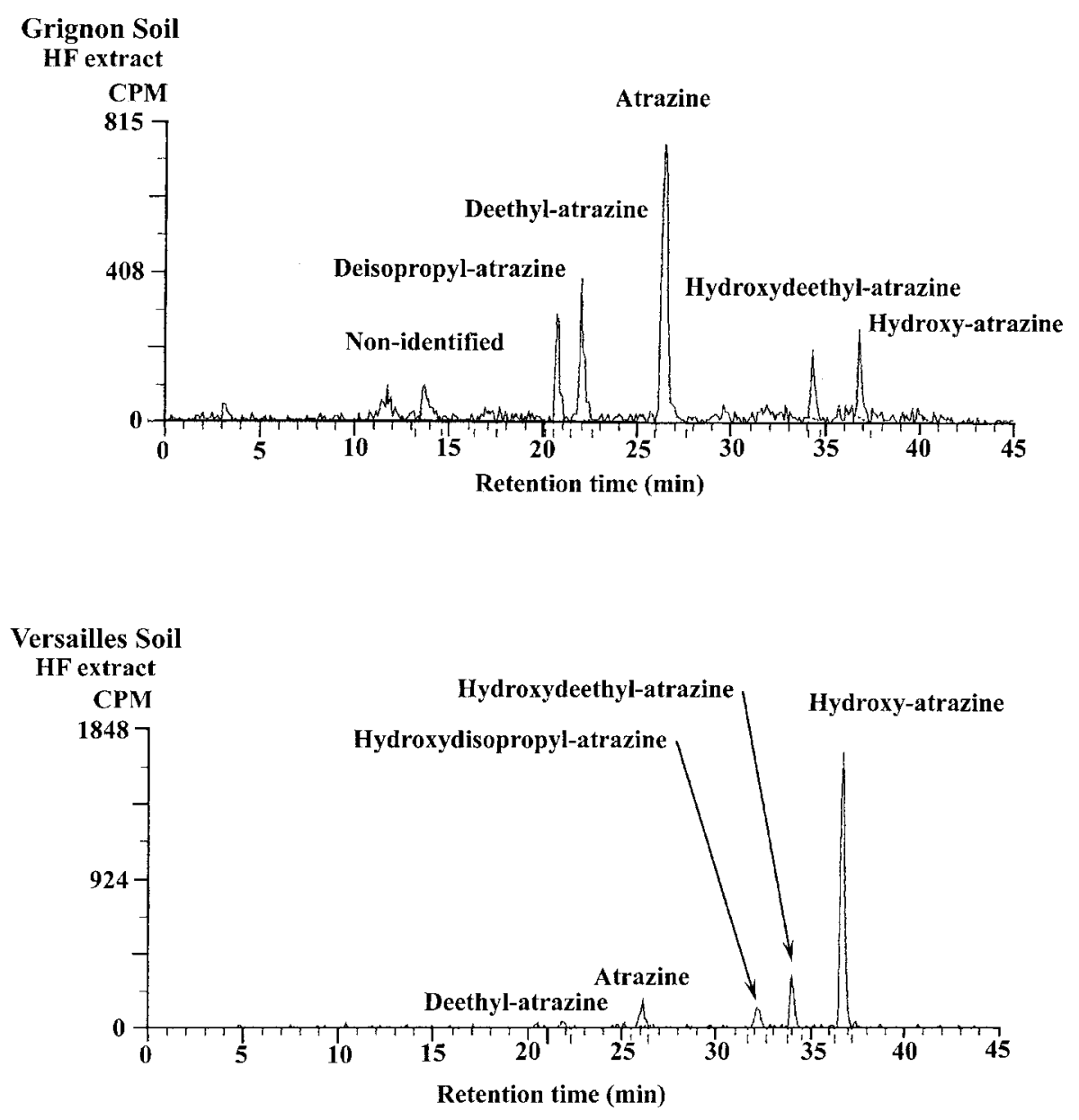

Figure 2. Metabolic profiles shown by ${ }^{14} \mathrm{C}$-chromatograms obtained for the HF extracts of Grignon and Versailles soils.

\subsection{Bound residue release from humins by acid hydrolysis}

Acid hydrolysis is largely used to characterise soil and sediment organic matter. The more chemically labile organic compounds are hydrolysed, mainly by breaking of the heteroatomic bonds [6]. This technique enables isolation a refractory nonhydrolysed fraction which corresponds to the fraction of organic matter the most chemically stable [3].

Acid hydrolysis of humin allowed to release more than $85 \%$ of the ${ }^{14} \mathrm{C}$ of the different humins of G-20 and V-0.5 (Tab. VII). The only metabolite identified in all the hydrolysates was hydroxyatrazine. Its proportion in the hydrolysates increased when the mineral constituents were destroyed by the HF treatment. In the humin with minerals (before HF treatment), hydroxy-atrazine in the hydrolysates represented 45.1 and $40.9 \%$ of the radioactivity released for G-20 and V-0.5 respectively; while without minerals (after HF treatment), hydroxy-atrazine represented 51.0 and $58.3 \%$ of the hydrolysed radioactivity for G-20 and $\mathrm{V}-0.5$, respectively. Like the metabolic profile of the bound residues released with the FA, proportions of the hydroxy-atrazine were highest in the acid soil. The other radioactivity in the humin hydrolysates corresponded to the non-identified products, new compounds formed during acid hydrolysis or unknown metabolites chemically bound to the humin and released during the hydrolysis.

The non-hydrolysed fractions of the humins contained between 2.4 and $9.1 \%$ of the ${ }^{14} \mathrm{C}$-bound residues of the fraction $<50 \mu \mathrm{m}$. If the hypotheses 
Table VII. Distribution of the ${ }^{14} \mathrm{C}$-bound residues of humins, obtained after alkaline extraction of the fraction $<50 \mu \mathrm{m}$ with or without HF treatment, between the acid hydrolysate of humin and non-hydrolysed humin (refractory humin), and quantification of the atrazine identified in the hydrolysed humin.

\begin{tabular}{|c|c|c|c|c|c|c|}
\hline \multirow[t]{2}{*}{ Humins } & $\begin{array}{l}\text { Hydrolysed } \\
\text { humin }\end{array}$ & $\begin{array}{l}\text { Hydroxy- } \\
\text { atrazine }\end{array}$ & $\begin{array}{c}\text { Refractory } \\
\text { humin }\end{array}$ & $\begin{array}{c}\text { Hydrolysed } \\
\text { humin }\end{array}$ & $\begin{array}{c}\text { Hydroxy- } \\
\text { atrazine }\end{array}$ & $\begin{array}{c}\text { Refractory } \\
\text { humin }\end{array}$ \\
\hline & \multicolumn{3}{|c|}{ (\% bound residues) } & \multicolumn{3}{|c|}{ (\% ${ }^{14} \mathrm{C}$ applied) } \\
\hline \multicolumn{7}{|c|}{ Without HF treatment } \\
\hline G-20 & 66.1 & 29.8 & 9.1 & 11.8 & 5.3 & 1.6 \\
\hline $\mathrm{V}-0.5$ & 37.8 & 19.3 & 4.4 & 21.4 & 8.7 & 3.7 \\
\hline \multicolumn{7}{|c|}{ After HF treatment } \\
\hline G-20 & 45.7 & 18.7 & 7.9 & 6.7 & 3.4 & 0.8 \\
\hline V-0.5 & 15.1 & 8.8 & 2.4 & 7.1 & 4.1 & 1.1 \\
\hline
\end{tabular}
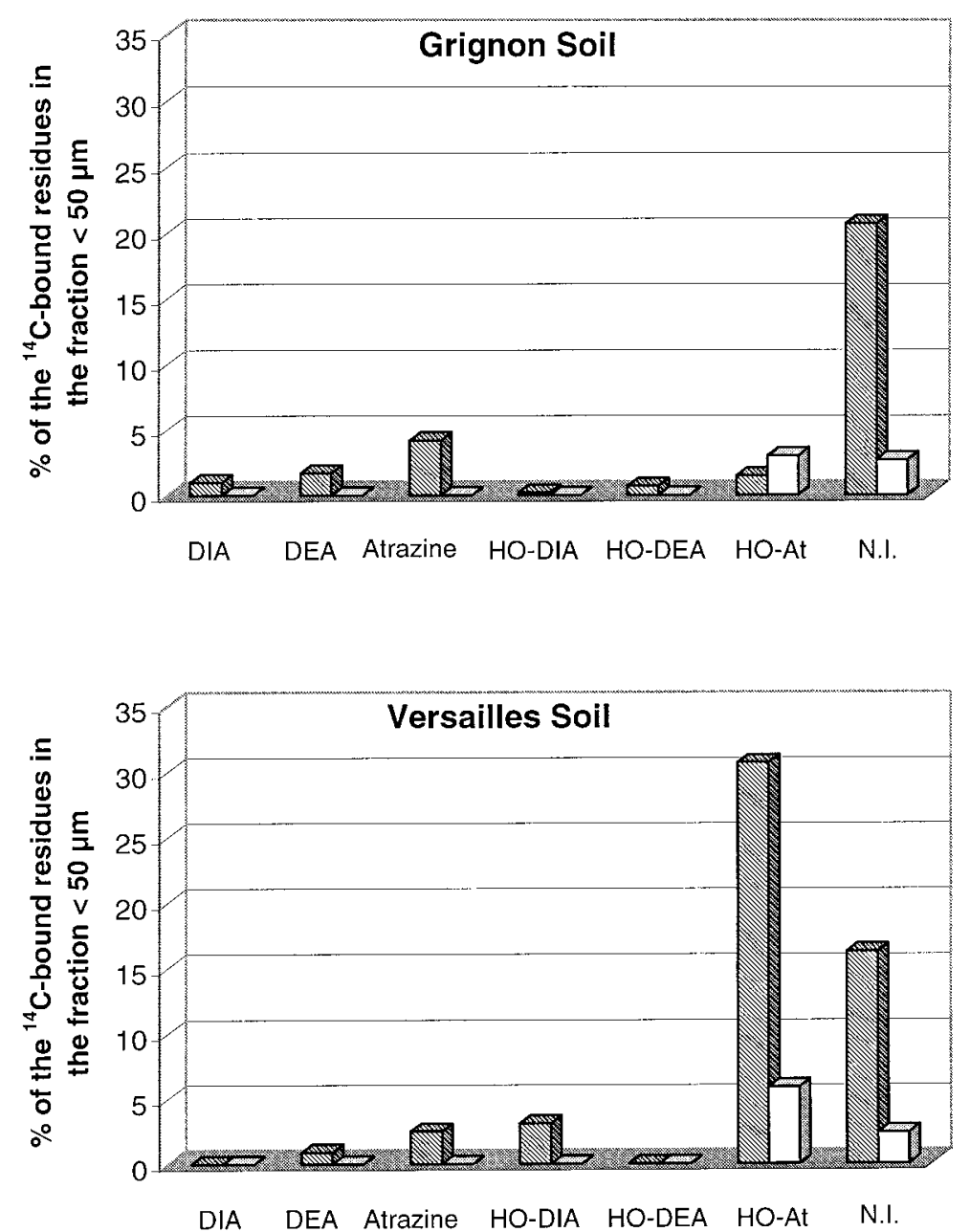

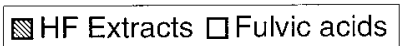

Figure 3. Balance of the ${ }^{14} \mathrm{C}$-bound residues released in the HF extracts and in fulvic acids after HF treatment for G-20 and V-0.5 (percentage of ${ }^{14} \mathrm{C}$-bound residues in the fractions $<50 \mu \mathrm{m}$ ): deisopropyl-atrazine (DIA), deethylatrazine (DEA), hydroxy-deisopropyl-atrazine (HO-DIA), hydroxy-deethyl-atrazine (HODEA), hydroxy-atrazine (HO-At), and ${ }^{14} \mathrm{C}$ soluble but non-identified (NI). 


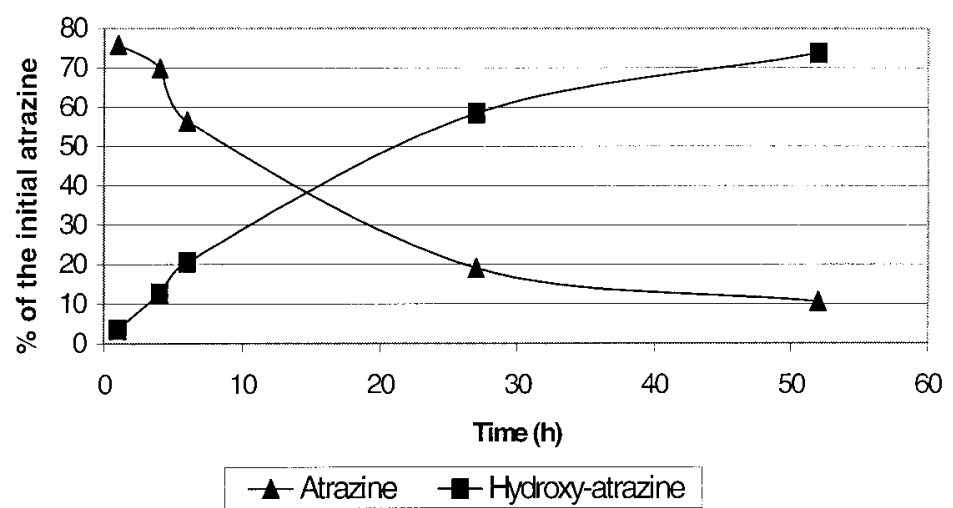

Figure 4. Hydrolysis kinetics of atrazine by HF $2 \%$.

used for the evaluation of the chemical stability of the soil organic matter are retained, we can hypothesise that these non-hydrolysable fractions represent the more stable bound residues.

\section{Conclusion}

The techniques used in this study allowed to release between $77.2 \%$ and $89.2 \%$ of the ${ }^{14} \mathrm{C}$ bound residues associated with the humified fraction $(<50 \mu \mathrm{m})$. Humin appeared like a stock place of bound residues, mainly in alkaline soil. In the acid soil, a larger proportion of bound residues is associated to the soluble humic compounds with a fulvic nature, extracted directly by an alkaline extraction or after elimination of the mineral constituents by HF treatment (Fig. 5). For the two soils studied, the more organic carbon was made soluble, the more bound residues were released. These results suggested that organic matter is largely responsible of the bound residues formation and that mineral components would have an important role by the way of physical protection of the soil organic matter.

Chromatographic analysis conducted on the different extracts allowed to identified between $31.6 \%$ and $51.9 \%$ of the ${ }^{14} \mathrm{C}$-bound residues of the humified fraction $(<50 \mu \mathrm{m})$. Obtaining ${ }^{14} \mathrm{C}$-atrazine in the HF extracts confirmed the formation of atrazine bound residues by physical entrapment. During the

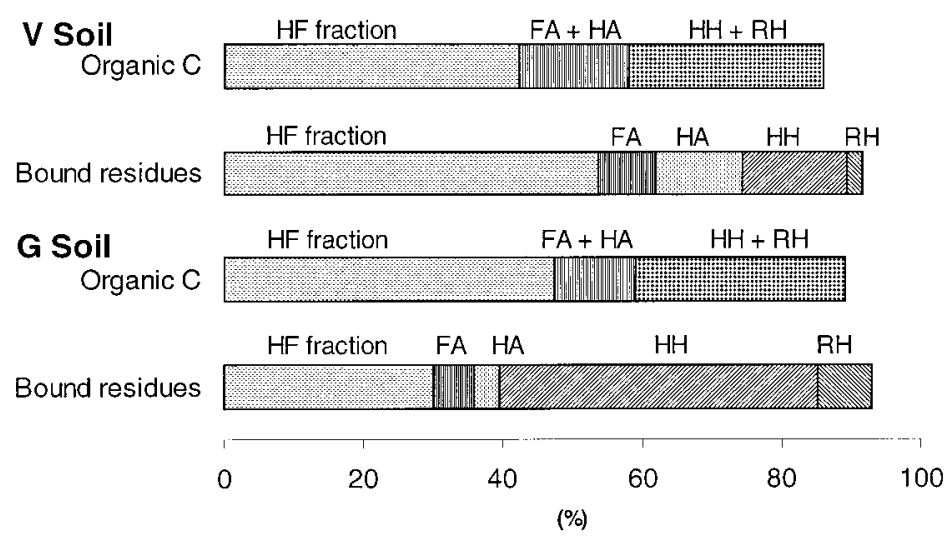

Figure 5. Distribution of bound residues (in percentage of the bound residues of the fraction $<50 \mu \mathrm{m}$ ) and organic carbon (in percentage of organic carbon of the fraction $<50 \mu \mathrm{m}$ ) between the HF fraction, fulvic acids (FA), humic acids (HA), hydrolysed humin (HH), and refractory humin $(\mathrm{RH})$ for the fraction $<50 \mu \mathrm{m}$ of $\mathrm{G}-20$ and V-0.5. 
different treatment used, atrazine is partly hydrolysed in hydroxy-atrazine by the reagents used $(\mathrm{NaOH}, \mathrm{HCl}, \mathrm{HF})$. In the view of these results, four reasons could explain the obtaining of large parts of hydroxy-atrazine in the different fractions: (i) Hydroxy-atrazine was covalently bonded to the organic matter of the fractions obtained, and the bond broke during the treatment used. (ii) Hydroxyatrazine was entrapped in the tri-dimensional structure of organo-mineral complex of soils, and released by the structural modification caused by the treatment used. (iii) Atrazine was covalently bonded to organic matter, the bond broke during the treatment and the atrazine released was hydrolysed by the reagent. (iv) Atrazine was entrapped, released during the treatment, and hydrolysed by the reagent.

A combination of these mechanisms was also feasible, but in all cases, these results indicated that if covalent binding between atrazine and/or hydroxy-atrazine and soil organic matter exists, the bond formed was on the chlorinated position of the triazine ring. This conclusion is based on the identification of degradation products not affected on the lateral chains.

Acknowledgements: The authors wish to thank Véronique Ethiévant and Valérie Bergheaud for technical assistance.

\section{References}

[1] Aly M.A.S., Dauterman W.C., Bioavailability, biological activity and characterization of bound residues of diflubenzuron in wheat, J. Environ. Sci. Health B27 (1992) 113-123.

[2] Aly M.A.S., Dauterman W.C., Bioavailability, biological activity and characterisation of bound residues of fenvarelate in wheat, J. Environ. Sci. Health B27 (1992) 223-233.

[3] Augris N., Balesdent J., Mariotti A., Derenne S., Largeau C., Structure and origin of insoluble and nonhydrolysable, aliphatic organic matter in a forest soil, Org. Geochem. 28 (1998) 119-124.

[4] Barriuso E., Houot S., Rapid mineralization of the $s$-triazine ring of atrazine in soils in relation to soil management, Soil Biol. Biochem. 28 (1996) 1341-1348.
[5] Barriuso E., Koskinen W.C., Incorporating nonextractable atrazine residues into soil size fractions as a function of time, Soil Sci. Soc. Am. J. 60 (1996) $150-157$.

[6] Barriuso E., Portal J.M., Andreux F., Cinétique et mécanisme de l'hydrolyse acide de la matière organique d'un sol humifère de montagne, Can. J. Soil Sci. 67 (1987) 647-658.

[7] Barriuso E., Schiavon M., Andreux F., Portal J.M., Localization of atrazine non-extractable (bound) residues in soil size fractions, Chemosphere 22 (1991) 1131-1140.

[8] Bollag J.M., Myers C.J., Minard R.D., Biological and chemical interactions of pesticides with soil organic matter, Sci. Total Environ. 123/124 (1992) 205-217.

[9] Calderbank A., The occurrence and significance of bound pesticide residues in soil, Rev. Environ. Contam. Toxicol. 108 (1989) 71-103.

[10] Capriel P., Haisch A., Persistenz von Atrazin und seiner Metaboliten im Boden nach einmaliger Herbizidanwendung, Z. Pflanzenernähr. Bodenkd. 146 (1983) 474-480.

[11] Capriel P., Haisch A., Khan S.U., Distribution and nature of bound (nonextractable) residues of atrazine in a mineral soil nine years after the herbicide application, J. Agric. Food Chem. 33 (1985) 567-569.

[12] Dec J., Bollag J.M., Microbial release and degradation of catechol and chlorophenols bound to synthetic humic acid, Soil Sci. Soc. Am. J. 52 (1988) 1366-1371.

[13] Dec J., Bollag J.M., Determination of covalent and non-covalent binding interactions between xenobiotic chemicals and soil, Soil Sci. 162 (1997) 858-874.

[14] Dec J., Haider K., Benesi A., Rangaswamy V., Schäffer A., Plücken U., Bollag J.M., Analysis of soilbound residues of ${ }^{13} \mathrm{C}$-labeled fungicide cyprodinil by NMR spectroscopy, Environ. Sci. Technol. 31 (1997) 1128-1135.

[15] Dec J., Haider K., Schäffer A., Fernandes E., Bollag J.M., Use of a silylation procedure and ${ }^{13} \mathrm{C}$-NMR spectroscopy to characterize bound and sequestered residues of cyprodinil in soil, Environ. Sci. Technol. 31 (1997) 2991-2997.

[16] Fuhremann T.W., Lichtenstein E.P., Release of soil-bound methyl $\left[{ }^{14} \mathrm{C}\right]$ parathion residues and their uptake by earthworms and oat plants, J. Agric. Food Chem. 26 (1978) 605-610.

[17] Gan J., Becker L., Koskinen W.C., Bulher D.D., Degradation of atrazine in two soils as a function of concentration, J. Environ. Qual. 25 (1996) 1064-1072. 
[18] Guthrie E.A., Bortiatynski J.M., Van Heemst J.D.H., Richman J.E., Hardy K.S., Kovach E.M., Hatcher P.G., Determination of $\left[{ }^{13} \mathrm{C}\right]$ pyrene sequestration in sediment microcosms using flash pyrolysis-GCMS and ${ }^{13} \mathrm{C}$ NMR, Environ. Sci. Technol. 33 (1999) 119-125.

[19] Hayar S., Munier-Lamy C., Chone T., Schiavon M., Physico-chemical versus microbial release of ${ }^{14} \mathrm{C}$ atrazine bound residues from a loamy clay soil incubated in laboratory microcosms, Chemosphere 34 (1997) 2683-2697.

[20] Houot S., Topp E., Yassir A., Soulas G., Dependence of accelerated degradation of atrazine on soil $\mathrm{pH}$ in French and Canadian soils, Soil Biol. Biochem. (in press).

[21] Khan S.U., Plant uptake of unextracted (bound) residues from an organic soil treated with prometryn, J. Agric. Food Chem. 28 (1980) 1096-1098.

[22] Khan S.U., Hamilton H.A., Extractable and bound (nonextractable) residues of prometryn and its metabolites in an organic soil, J. Agric. Food Chem. 28 (1980) 126-132.

[23] Khan S.U., Ivarson K.C., Microbial release of unextracted (bound) residues from an organic soil treated with prometryn, J. Agric. Food Chem. 29 (1981) 1301-1303.
[24] Nieman J.K.C, Sims R.C., Sims J.L., Sorensen D.L., McLean J.E., Rice J.A., $\left[{ }^{14} \mathrm{C}\right]$-pyrene bound residue evaluation using MIBK fractionation method for creosote-contaminated soil, Environ. Sci. Technol. 33 (1999) 776-781.

[25] Roberts T.R., Klein W., Still G.G., Kearney P.C., Dresher N., Desmoras J., Esser H.O., Aharonson N., Vonk J.W., Non-extractable pesticide residues in soils and plants, Pure Appl. Chem. 56 (1984) 945-956.

[26] Schiavon M., Soulas G., Étude de la contamination des eaux de drainage et de la matière organique du sol par l'atrazine et ses dérivés de dégradation, Ministère Environnement, 1983, Convention No. 81398.

[27] Scheunert I., Schröder P., Formation, characterization and release of non-extractable residues of $\left[{ }^{14} \mathrm{C}\right]-$ labeled organic xenobiotics in soils, Environ. Sci. Pollut. Res. 5 (1998) 236-244.

[28] Skjernstad J.O., Clarke P., Taylor J.A., Oades J.M., Newman R.H., The removal of magnetic materials from surface soils. A solid state ${ }^{13} \mathrm{C}$ CP/MAS N.M.R. study, Aust. J. Soil Res. 32 (1994) 1215-1229.

[29] Xie H., Guetzloff T.F., Rice J.A., Fractionation of pesticide residues bound to humin, Soil Sci. 162 (1997) 421-429. 